Prekariat - perspektywa katolickiej nauki społecznej, red. J. Mazur OSPPE, ks. Ł. Marczak, Kraków 2017

(Spotkania Naukowe Wykładowców Katolickiej Nauki Społecznej, XIII), s. 75-107.

DOI: http://dx.doi.org/10.15633/9788374385985.05

Józefina Hrynkiewicz

Uniwersytet Warszawski

\title{
Fenomen prekariatu jako wyzwanie dla współczesnej polityki społecznej
}

Przyczyny pojawienia się w Europie prekariatu w ostatnich dwóch dziesięcioleciach XX wieku trudno wytłumaczyć względami ekonomicznymi, społecznymi lub demograficznymi. Przy próbie poznania oraz wyjaśnienia przyczyn szybkiego rozwoju prekariatu pod koniec XX i na początku XXI wieku mimo woli nasuwa się porównanie z sytuacją sprzed dwóch wieków, gdy na przełomie XVIII i XIX wieku powstawał proletariat fabryczny. Powstawanie proletariatu miało jasno określone przyczyny ekonomiczne, społeczne i demograficzne. Zanikał stan rzemieślniczy i produkcja jednostkowa. Zastosowanie w przemyśle nowej technologii (maszyna parowa) oraz nowej organizacji pracy wywołało szybki rozwój masowej produkcji fabrycznej oraz ogromny popyt na pracę niewykwalifikowanych robotników. Gwałtowny rozwój produkcji fabrycznej przemysł "pochłaniał” wszystkie wolne zasoby pracy: wyzwalanych z pańszczyzny chłopów, pracowników bankrutujących warsztatów rzemieślniczych, niepracujące dotychczas zarobkowo kobiety, a także dzieci. Niewielkie wymagania dotyczące kwalifikacji robotników, masowe zatrudnianie kobiet i dzieci spowodowało poważne obniżenie wynagrodzeń za pracę. Robotnik nie musiał już zarabiać na utrzymanie rodziny oraz wychowania swojego następcy, aby „ród robotników nie wymarł 
w jednym pokoleniu"'; kobiety i dzieci same musiały zarobić na własne utrzymanie. To, co wcześniej pracodawca musiał zapłacić robotnikowi, aby utrzymał własną rodzinę i wychował następców, podzielono na wynagrodzenie robotnika, jego żony i dzieci. Nisko wyceniana praca robotnika pozwoliła na znaczne obniżenie kosztów produkcji fabrycznej oraz wysoką akumulację kapitału.

Masowe zatrudnienie i tania praca („tania siła robocza”) powodowały bardzo rozległe negatywne skutki we wszystkich wymiarach życia społecznego i ekonomicznego, a złe warunki życia i pracy pogarszały sytuację demograficzną. Naruszyło to podstawowe zasady kształtujące ład społeczny, prowadząc do rozdźwięku między wartościami i zasadami ekonomicznymi a moralnymi. $\mathrm{Z}$ tego rozdźwięku narodził się w XIX wieku proletariat; robotnicy dla utrzymania życia podejmowali pracę za głodowe wynagrodzenie. Wraz z proletariatem powstawała kwestia społeczna, nazywana w publicystyce „złowrogim widmem”, zagrażającym porządkowi społecznemu i gospodarczemu, który ją wytworzył. Bezpośrednio zagrażała istnieniu społeczeństwa i państwa; była „najściem barbarzyńców z łona samego społeczeństwa”, była zagrożeniem dla stosunków ekonomicznych, ładu społecznego i moralnego ${ }^{2}$. Konieczność ochrony zagrożonego destrukcją ładu społecznego to główna przyczyna systemowych działań, które podejmowało państwo od przełomu wieków XVIII i XIX. Problemy

1 Powszechnie odstąpiono od respektowania zasady wynagradzania robotnika sformułowanej przez Adama Smitha. Według Smitha robotnik musi zarobić tyle, aby sam się utrzymał oraz wychował swoich następców, gdyż inaczej nie byłoby następnego pokolenia, bo ród robotników wymarłby w jednym (pierwszym) pokoleniu. Wynagrodzenie miało pozwolić na utrzymanie pracownika, jego żony i dzieci. Powinno też zawierać jakąś nadwyżkę, „coś więcej ponad to", co potrzebne do przeżycia pracownika i rodziny. Ile więcej „ponad to", co niezbędne dla zachowania życia, ma wynosić płaca, tego Smith już „nie podejmuje się określić”. Zob. A. Smith. Badania nad natura i przyczynami bogactwa narodów, tł. Z. Sadowski, wyd. II, Warszawa 2013, s. $81 n n$.

2 Szerzej o kwestii społecznej w: J. Hrynkiewicz, Kwestia społeczna w pracach Ludwika Krzywickiego, Warszawa 2010. 
prowadziły do kumulowania się skutków wielu nierozwiązanych problemów ukształtowanych wskutek żywiołowych przemian gospodarczych; wraz z rosnącą liczbą proletariuszy poważnie zagrażały one porządkowi ekonomicznemu i społecznemu. Od początku XIX wieku stawało się coraz powszechniej wiadome, że warunkiem przetrwania porządku ekonomicznego, ładu moralnego i państwa, przedsiębiorców i pracowników jest rozwiązanie kwestii społecznej, gdyż niosła ona ze sobą coraz rozleglejsze negatywne skutki ${ }^{3}$.

Początkowa reakcja państwa polegająca na „łagodzeniu skutków" kwestii społecznej okazała się nieskuteczna ${ }^{4}$. Wobec skumulowanych, szybko narastających negatywnych skutków nierozwiązanych problemów społecznych ograniczona reakcja przerodziła się w daleko posuniętą ingerencję państwa w regulowanie procesów ekonomicznych, społecznych i demograficznych. Systematycznie następowały daleko idące ograniczenia samowoli przedsiębiorców. Powołano państwową ochronę pracy, prawo i sądy pracy, podniesiono wiek pozwalający zatrudniać dzieci, uregulowano czas pracy i wynagrodzenia, wyznaczono dni wolne od pracy, wprowadzono obowiązkowe ubezpieczenie społeczne oraz trójstronne instytucje rozstrzygające spory i konflikty. W rozwiązywanie kwestii społecznej angażowało się oprócz państwa wiele podmiotów: Kościoły, związki pracodawców i pracowników, partie polityczne, stowarzyszenia, środowiska nauki. Pojawiały się inicjatywy międzyna-

${ }^{3}$ Kwestia społeczna (niem. soziale Frage, ang. critical problem) to nieznana wcześniej w dziejach dysocjacja wartości moralnych i ekonomicznych. W XIX wieku pojęcia tego używano do określenia ogółu negatywnych skutków społecznych żywiołowo rozwijającej się gospodarki kapitalistycznej, wyrażających się w zaburzeniach rozwoju demograficznego wywołanych masowym zatrudnianiem kobiet i dzieci do pracy fabrycznej, kilkunastogodzinną pracą, niskimi płacami i niskim poziomem życia pracujących, rozstrojem rodziny i ładu społecznego, narastającymi nierównościami społecznymi.

${ }^{4}$ Uchwalone w Wielkiej Brytanii w 1601 i 1801 prawo ubogich czy zorganizowane dla bezdomnych i włóczących się „domy pracy przymusowej”, surowe kary za organizowanie się robotników szybko okazały się niewystarczające dla rozwiązania problemów społecznych obejmujących coraz większą część społeczeństwa. 
rodowe wskazujące rozwiązania. Powstały organizacje ochrony migrujących za pracą. Z poszukiwania sposobów likwidacji narastających negatywnych skutków kwestii społecznej w XIX wieku powstała i rozwijała się przez następne dziesięciolecia polityka społeczna. Jej podmiotem stało się państwo, które może stosować wszystkie instrumenty polityki społecznej; tworzyć i stosować prawo, powoływać instytucje, ustanawiać reguły podziału dochodu społecznego, tworzyć programy oraz kontrolować i nadzorować ich realizację. Procesy rozwoju polityki społecznej - przy szerokim zaangażowaniu wielu instytucji międzynarodowych - kontynuowano w XX wieku.

Rozwój instytucji polityki społecznej napotykał na zdecydowany opór przedsiębiorców, którzy traktowali pracę jak towar, nie dopuszczając państwa do ingerowania $\mathrm{w}$ procesy gospodarcze ukształtowane na zasadach nieograniczonej wolności. Poważnym osiągnięciem państwa w XIX wieku było uzyskanie (wymuszenie) zgody pracodawców na rezygnowanie z przymusu zatrudnienia. Pracodawcy z trudem godzili się na zrezygnowanie przymusu zatrudnienia i wprowadzenie wolności zawierania umów o pracę. Bronili wolnorynkowej zasady wynagradzania; robotnikowi płacono tyle, ile wynosiła wartość chleba potrzebnego do przeżycia. Niskie wynagrodzenie uzasadniano nadmiarem taniej „siły roboczej” oraz względami moralnymi (wysokie płace miały sprzyjać lenistwu i demoralizacji). Tania siła robocza skłaniała do zatrudniania w fabrykach i kopalniach, pod ziemią, nie tylko mężczyzn, ale także kobiety i dzieci. Ingerowanie państwa w procesy, które miały być regulowane „niewidzialną ręką rynku” spotykało się z protestem przedsiębiorców, bo naruszało ich wolność gospodarczą, było niepotrzebne i szkodliwe dla wolnej gospodarki. Przedsiębiorcy długo nie ustępowali, a państwo było zbyt słabe wobec siły kapitału. Postawa państwa zmieniła się pod wpływem raportów dowództwa armii brytyjskiej. Wskazywały one na spadek siły obronnej państwa spowodowany złą sytuacją demograficzną Wielkiej Brytanii. Straty ludnościowe spowodowane 
szkodliwym i marnotrawnym zatrudnianiem m.in. kobiet i dzieci w fabrykach i pod ziemią, w kopalniach, skutecznie mógł zahamować tylko rząd. Zła sytuacja demograficzna zaburzała nie tylko funkcje obronne państwa („nie było z czego brać rekruta”). Zła kondycja fizyczna młodych pokoleń robotników, od bardzo wczesnego wieku zatrudnianych w fabrykach i kopalniach, zagrażała gospodarce, narodowi i państwu. Uprzedmiotowienie pracownika powodowało głęboką deformację procesu pracy, degradowało podstawy ładu społecznego i moralnego, zagrażało gospodarce. Negatywnie wpływało na stan ludności, na powstawanie i rozwój rodzin, zaburzało procesy trwałego następstwa pokoleń, zagrażało biologicznemu przetrwaniu narodu i pokojowym stosunkom społecznym. Jednak dopiero pod groźbą utraty zdolności do obrony państwo podjęło skuteczną ochronę potencjału demograficznego $\mathrm{kraju}^{5}$. Zagrożenie funkcji obronnej państwa z powodu złej sytuacji społecznej i demograficznej zmusiło rządy do tworzenia innych form ochrony, usuwania deformacji ustroju pracy oraz nadużyć kapitału wobec pracowników.

Ingerencja państwa w mechanizmy wolnego rynku pracy nasila się w Europie na przełomie wieków XVIII i XIX i będzie trwała do ostatnich dekad XX wieku. Reakcja państwa na procesy żywiołowego rozwoju gospodarki kapitalistycznej nie była doraźną zmianą postawy. Była to zasadnicza systemowa zmiana funkcji państwa, które porzuciło neutralną, pasywną postawę wobec zagrożeń płynących z żywiołowo rozwijającej się gospodarki kapitalistycznej. Państwo przyjęło funkcję aktywną wówczas, gdy

5 Pierwsze reformy naruszające „wolność” gospodarczą wprowadzono w Anglii. W 1834 w Wielkiej Brytanii utworzono państwową inspekcję pracy. W kolejnych latach podobne państwowe instytucje powołano w Niemczech, we Francji i innych państwach. W pierwszej fazie inspekcje pracy objęły ochroną pracę dzieci i kobiet, warunki i czas pracy oraz wynagrodzenia. W połowie XIX wieku powstają związki zawodowe, których działania mają istotne znaczenie ochronne dla pracujących. Szerzej por. J. Kuliszer, Powszechna historia gospodarcza średniowiecza i czasów nowożytnych, Warszawa 1961, t. II, s. 189nn. 
żywiołowy i wolny rozwój gospodarki zagrażał destrukcją jego instytucjom, chaosem i rozstrojem systemu, także systemu gospodarki. Systemowe rozwiązywanie problemów społecznych podjęto z powodu zagrożenia bezpieczeństwa państwa z przyczyn demograficznych oraz w związku z nasilającymi się buntami, strajkami i wystąpieniami organizujących się politycznie robotników. Wymienione przyczyny skłoniły rząd angielski do utworzenia państwowej instytucji ochrony pracy i sądownictwa pracy, do uregulowania zatrudnienia i wynagrodzenia, ograniczenia wieku zatrudnianych dzieci. Poprawiano warunki pracy, wprowadzono ustawowy zakaz zatrudniania dzieci i kobiet do pracy w kopalniach pod ziemią ${ }^{6}$, skracano dobowy czas pracy, wprowadzono prawo do świętowania niedzieli, podniesiono płace, zastosowano płace minimalne. Powołano państwowe instytucje: ochrony dialogu społecznego, usankcjonowano prawo zakładania i działania związków zawodowych pracowników najemnych. Z inicjatywy i pod opieką państwa wprowadzono dla robotników (później dla pozostałych pracowników i służb) powszechne instytucje ubezpieczenia społecznego. Obowiązkowym ubezpieczeniem społecznym, finansowanym przez państwo, pracowników i pracodawców, objęto chorobę, wypadki, inwalidztwo, sieroctwo, starość, bezrobocie. Ubezpieczenia społeczne stały się rzeczywistym aktem trwałego „porzucenia” przez państwo „neutralnej” funkcji i postawy wobec położenia ekonomicznego pracowników ${ }^{7}$. Wprowadzając

${ }^{6}$ Zakaz pracy kobiet w kopalniach pod ziemią wprowadzono powszechnie na mocy 45 Konwencji MOP w 1935. Jednak w 2005 ETS w sprawie C-2003/03 przeciwko Austrii uznał, że 45 Konwencja nie odpowiada zasadzie równego traktowania kobiet i mężczyzn w zakresie zatrudnienia, kształcenia i awansu zawodowego oraz warunków pracy. ETS wezwał państwa do wymówienia tej konwencji. Polska w 2008zainicjowała prace nad wymówieniem konwencji.

7 Ubezpieczenia społeczne uważane są za podstawę państwa opiekuńczego. Powszechnie uznaje się je za „wynalazek brytyjski”, za „wytwór socjalistów i liberałów”. Trzeba przypomnieć, że pierwsze ubezpieczenia społeczne wprowadził w Niemczech Otto von Bismarck. Niemieckie ubezpieczenia stały się modelowym rozwiązaniem stosowanym powszechnie w Unii 
ubezpieczenie społeczne, państwo dawało robotnikom trwałą gwarancję pomocy w przypadku każdego zdarzenia losowego, które uniemożliwiało pozyskanie środków utrzymania $\mathrm{z}$ własnej pracy, tym samym zapewniało pracownikom wolność od skrajnego ubóstwa. Ubezpieczenia społeczne dawały trwałe podstawy utrzymania pokoju społecznego, zagrożonego „niepewnością jutra" m.in. z powodu cyklicznych kryzysów gospodarczych.

Do rozwiązywania kwestii społecznej w XIX wieku włączały się liczne instytucje, organizacje społeczne i ruchy polityczne. Realizacja zadań polityki społecznej państwa była możliwa dzięki zaangażowaniu wielu podmiotów w regulowanie zatrudnienia i ochronę pracowników. Od połowy XIX wieku wiele miejsca zagadnieniom pracy i położenia robotników poświęcała katolicka nauka społeczna ${ }^{8}$. W XIX wieku (także w wieku XX) kwestia robotnicza (społeczna) stała się przedmiotem prac i dokumentów katolickiej nauki społecznej. Biskup Wilhelm Emmanuel von Ketteler proponował rozwiązywanie kwestii społecznej we współzależności polityki i etyki ${ }^{9}$. Papież Leon XIII w encyklice Rerum novarum (1891) sformułował zasady i zadania państwa w zakresie polityki społecznej. Polityka społeczna w XIX i XX wieku przyniosła istotną poprawę warunków pracy i życia pracowników. W ocenie

Europejskiej. Szerzej: N. Ferguson, Potega pieniądza. Finansowa historia świata, tł. T. Kunz, Kraków 2010, s. 202nn.

${ }^{8}$ Wilhelm Emmanuel von Ketteler (1811-1877) - biskup, prawnik i teolog, angażował się w poprawę warunków bytu i pracy robotników. Jego teoria społeczna opiera się na badaniu i analizowaniu zależności między pracą a własnością. Na podstawie badań i obserwacji wysuwał propozycje rozwiązywania narastających problemów społecznych. „Jeśli chcemy poznać czas, musimy próbować zgłębić problem socjalny. Kto go nie zrozumie, dla niego współczesność i przyszłość pozostają zagadką". Szerzej zob.: K. Szewior, Wilhelm Emmanuel Ketteler - prekursor katolickiej nauki spoŁecznej w Niemczech, http://www.kns.gower.pl/knp/ketteler.htm (20.10.2013), s. 1. Ogłoszenie w 1891 encykliki Rerum novarum poprzedziły prace biskupa Wilhelma Emanuela von Kettelera (uważanego za prekursora katolickiej nauki społecznej).

9 K. Szewior, Wilhelm Emmanuel Ketteler..., dz. cyt. 
katolickiej nauki społecznej były one wciąż niedostateczne; w dokumentach Kościoła katolickiego stale podnoszono nierozwiązane problemy położenia materialnego pracowników oraz ich rodzin, poszanowania godności oraz podmiotowości pracy. W encyklikach Laborem exercens (1981) i Centesimus annus (1991) Jan Paweł II, rozważając współczesne problemy społeczne związane $\mathrm{z}$ pracą ludzką, wynikające $\mathrm{z}$ braku podmiotowości i poszanowania godności pracownika, stwierdza, że „praca jest kluczem do rozwiązania kwestii społecznej”; nowej kwestii społecznej, jaka pojawiła się w końcu XX wieku, po blisko 100 latach od ogłoszenia encykliki Rerum novarum. Jan Paweł II na określenie najważniejszego problemu społecznego końca XX wieku używa archaicznego określenia, jakim stała się „kwestia społeczna” wskutek pogłębiającej się deformacji pracy ludzkiej. Nawiązując do encykliki Leona XIII Rerum novarum Jan Paweł II w encyklice Laborem exercens stwierdza, że istotą kwestii społecznej w końcu XX wieku stał się nierozwiązany problem pracy.

„Problem pracy kluczem do rozwiązania kwestii społecznej” oto podstawowa teza encykliki Laborem exercens ${ }^{10}$. Kluczowe zagadnienia współczesnej pracy to: brak podmiotowości pracownika, naruszona godność pracy, brak sprawiedliwego wynagrodzenia za pracę, niedostateczna ochrona pracownika i jego rodziny. Powstaje pytanie: dlaczego Jan Paweł II w końcu XX wieku przywołuje archaiczny termin „,kwestia społeczna”, którego używano w tekstach historycznych? Analiza problemów współczesnej pracy oraz ich wpływu na życie jednostki, rodziny i całego społeczeństwa wskazuje, że nie jest to użycie - w odniesieniu do pracy w ważnym dokumencie nauki społecznej Kościoła katolickiego - przypadkowe. Wskazanie problemów pracy jako klucza do rozwiązywania współczesnej kwestii społecznej wynika z głębokiego poznania

${ }^{10}$ Jan Paweł II, enc. Laborem exercens o pracy ludzkiej, nr 3; por. Leon XIII, enc. Rerum novarum o kwestii robotniczej. W końcu XIX wieku papież Leon XIII pisze: wynagrodzenie pracownika ma wystarczyć na utrzymanie siebie, żony i dzieci, ma mieć charakter rodzinny 
i rozumienia współczesnych problemów pracy oraz ich negatywnego wpływu na ogół procesów społecznych. W przeszłości pojęcie „kwestia społeczna” odnosiło się do problemów trudnych, zawikłanych, o rozległych konsekwencjach, wywołujących negatywne zjawiska i procesy społeczne. Kwestia społeczna to sytuacja, którą charakteryzuje głęboka „dysocjacja wartości moralnych i ekonomicznych". Jeżeli współcześnie Jan Paweł II używa pojęcia „kwestia społeczna” w odniesieniu do pracy, to znaczy, że w pracy, w zdeformowanych procesach pracy ludzkiej, postrzegał źródła tej kwestii i jej negatywne objawy, które mają wpływ na wszystkie wymiary życia ludzkiego.

Na przełomie wieków XX i XXI dynamicznie rósł udział zatrudnienia na umowę o dzieło, zlecenie, samozatrudnienie oraz inne zatrudnienie niestałe. Zaniepokojenie procesami deformacji pracy pojawiło się w literaturze przedmiotu w końcu XX wieku. Pojęcie underemployment sygnalizowało coraz bardziej zaawansowane zjawisko nasilającej się „elastyczności zatrudnienia”. Charakterystyczne cechy dynamicznego rozwoju „elastycznych” form zatrudnienia to niskie wynagrodzenie i niepełnowartościowa praca poniżej kwalifikacji pracownika, niestałe i doraźne zatrudnienie, podejmowane $\mathrm{z}$ konieczności egzystencjalnej (working poor $)^{11}$. W Polsce zjawisko „elastycznego” zatrudnienia pojawiło się $\mathrm{w}$ latach dziewięćdziesiątych wraz $\mathrm{z}$ podjęciem procesu transformacji systemowej. Rosło tak szybko, że w końcu pierwszej dekady XXI wieku było dwukrotnie wyższe niż średnia w państwach UE ${ }^{12}$. Niepewna, niepełnowartościowa praca doraźna, ubóstwo pracujących mimo zatrudnienia szybko znalazły nowa nazwę - prekariat $^{13}$.

11 Z badania GUS wynika, że w 2014 ok. 43 proc. osób w gospodarstwach domowych osiągało dochody poniżej minimum socjalnego. Badanie budżetów gospodarstw domowych 2014, GUS 2015.

12 Zatrudnienie na czas określony w polskiej gospodarce. Społeczne i ekonomiczne konsekwencje zjawiska., red. M. Bednarski, K. Frieske, Warszawa 2012, s. 12.

13 G. Standing, Prekariat. Nowa niebezpieczna klasa, Warszawa 2014. 
Fenomen prekariatu to cofnięcie się polityki społecznej do jej początków sprzed blisko dwóch wieków. Praca i problemy z nią związane stają się ponownie źródłem nowej kwestii społecznej, uprzedmiotowiona praca „kluczem” do jej rozwiązywania. Prekariat przełomu XX i XXI wieku pojawia się pomimo wielu rozwiązań: przyjęcia Powszechnej Deklaracji Praw Człowieka (1948), wdrożenia ważnego dokument normatywnego Rady Europy Europejskiej Karty Społecznej (nowelizowanej w latach 1961, 1991, 1996) - szeroko ujmującej problemy pracy i zatrudnienia ${ }^{14}$. W części o wynagrodzeniu za pracę Europejska Karta Społeczna stanowi, że wynagrodzenie wynika $\mathrm{z}$,prawa pracownika najemnego do godziwego wynagrodzenia za pracę", ma zapewniać wystarczający, godziwy poziom życia pracownikowi i jego rodzinie ${ }^{15}$. Zgodnie ze stanowiskiem Niezależnego Komitetu Ekspertów UE interpretacja zwrotów: „wystarczający poziom życia”, „wynagrodzenie godziwe”, winna uwzględniać szeroki kontekst ekonomiczny i społeczny państwa, możliwości pracodawców oraz poziom rozwoju państwa ${ }^{16}$. Polska przygotowując się do wstąpienia do UE, musiała wdrożyć

14 Europejska Karta Społeczna uchwalona w 1961, zrewidowana w 1966, ratyfikowana przez Polskę w 1991 i 1996. W 1948 w Powszechnej Deklaracji Praw Człowieka jednym z podstawowych praw człowieka ustanowiono prawo do zabezpieczenia społecznego. Większość praw socjalnych, powiązanych z zatrudnieniem, np. prawo do ubezpieczenia społecznego, należy w Unii Europejskiej do katalogu podstawowych praw obywateli.

15 „Wszyscy pracownicy mają prawo do godziwego wynagrodzenia za pracę, zapewniającego wystarczający poziom życia ich samych i ich rodzin. Europejska Karta Społeczna, art. 4, cz. I. Komitet Niezależnych Ekspertów Unii Europejskiej w 1966 określił kryterium godziwego wynagrodzenia: jest to $2 / 3$ lub 68 proc. przeciętnej płacy w kraju. Więcej zob.: Z. Salwa, Kodeks pracy. Komentarz, wyd. 8, Warszawa 2006. Polska ratyfikowała Europejską Kartę Społeczną.

16 Por.: G. Goździewicz, Refleksje na temat prawa do godziwego wynagrodzenia za prace, w: Wynagrodzenie za prace $w$ warunkach społecznej gospodarki rynkowej i demokracji, red. W. Sanetra, Warszawa 2009. W 1996 Komitet Niezależnych Ekspertów UE wskazał, że płaca godziwa powinna wynosić 60 proc. płacy netto w danym kraju (tzn. po potrąceniu podatku i składek, tzw. płaca „na rękę", czyli dochód netto z płacy). 
przepisy UE ${ }^{17}$. Organizacja Współpracy Gospodarczej i Rozwoju (OECD) zalecała, aby płaca godziwa wynosiła co najmniej 66 proc. produktu krajowego brutto w przeliczeniu na jednego mieszkańca danego kraju ${ }^{18}$. Według Międzynarodowej Organizacji Pracy najniższa płaca powinna wynosić 50 proc. przeciętnego wynagrodzenia $\mathrm{w}$ danym kraju ${ }^{19}$. Wymienione organizacje określają wysokość godziwego wynagrodzenia w granicach od 68 proc. do 65 proc. średniego wynagrodzenia. W sprawie wysokości wynagrodzenia są ze sobą zgodne różne, nierzadko odległe od siebie, podejścia ideowe, wyrastające $\mathrm{z}$ odmiennych założeń i systemów wartości. Wynagrodzenie za pracę ma zapewnić pracownikowi i jego rodzinie środki utrzymania, a także dostarczyć środków na wychowanie następcy, utrzymanie rodziny, uczestnictwo w życiu społecznym, świętowanie - to znaczy na uzyskanie godziwego poziomu życia, a więc takiego poziomu życia, który jest akceptowany w danym czasie i miejscu.

Analiza różnych koncepcji rozwiązywania problemów pracy wskazuje na szerokie i dogłębne ich ujmowanie. Tym bardziej jest całkowicie niezrozumiałe, dlaczego w wielu państwach Europy w końcu wieku XX powstaje prekariat? Jeżeli do analizy fenomenu prekariatu przyjmiemy interpretację i oceny wyrażone w dokumentach Kościoła katolickiego, to musimy postawić pytanie: czy w końcu wieku XX powróciła ta „przeklęta” kwestia społeczna z początku XIX wieku? Czy znów pojawiło się to dawne „złowrogie widmo" zagrażające porządkowi społecznemu? W jakich zjawiskach i procesach związanych ze współczesnymi stosunkami i warunkami pracy i zatrudnienia przejawiać się mają te negatywne zjawiska, które można nazywać współczesną kwestią społeczną?

${ }^{17}$ Europejska Karta Społeczna (zrewidowana) przyjęta w Strasburgu 3 maja 1996. Por. A. Świątkowski, Karta Praw Społecznych Rady Europy, Warszawa 2006.

18 T. Liszcz, Prawo pracy, Warszawa 2005.

19 Konwencja nr 131 MOP dotycząca ustalania płac minimalnych, zwłaszcza w odniesieniu do krajów rozwijających się. 
Najważniejszym problemem współczesnych stosunków pracy jest utracenie przez pracownika podmiotowości i godności, prawa do godnego wynagrodzenia oraz do ochrony jego praw i praw jego rodziny. Dotyczy to większej części pracujących, głównie jednak nowej grupy społecznej, nazwanej prekariatem, powstającej wskutek głębokiej deformacji zatrudnienia i pracy w strukturach społecznych współczesnych państw.

Czy przyczyny powstawania proletariatu i prekariatu mają cechy wspólne, mimo że oddziela je wiele pokoleń? Czy pojawienie się prekariatu w końcu XX wieku to wynik powstawania i dominacji w świecie neoliberalnej gospodarki globalnej, a wraz z nią głębokiej, porównywalnej z początkami rozwoju kapitalizmu, „dysocjacji wartości moralnych i ekonomicznych"?

Tak postawiony problem wymaga analiz, poszukiwania argumentów zaświadczających o podobnych przyczynach, które prowadziły do rozstroju wartości ekonomicznych i moralnych, przedmiotowego traktowania pracownika i jego pracy w wieku XIX, gdy powstał proletariat fabryczny, i w wieku XX, gdy powstał prekariat. Podobieństwo fonetyczne nazwy nowej, licznej grupy społecznej - prekariatu - z nazwą "proletariat” niewiele wyjaśnia. Porównywanie współczesnych warunków do sytuacji sprzed dwóch wieków nasuwa tym bardziej wiele wątpliwości. Wspólne cechy sytuacji, które doprowadziły do powstania na początku XIX wieku proletariatu, a w końcu XX wieku - prekariatu, to: pozbawienie lub nieprzyznanie pracownikowi prawa do ochrony pracy, do respektowania jego prawa pracy i zabezpieczenia społecznego. Podobnie jak proletariat w początkowym okresie, tak obecnie prekariat jest to grupa pozbawiona podmiotowości, rozproszona, nieorganizująca się w celu obrony i reprezentowania swych interesów. Prekariat, podobnie jak proletariat, stanowi grupę zróżnicowaną pod względem: wykształcenia, wynagrodzenia, sytuacji zawodowej, zajmowanego stanowiska, charakteru pracy, pozycji społecznej. Współcześni prekariusze to zarówno osoby bez kwalifikacji i wykształcenia, jak i osoby z wysokimi kwalifikacjami, 
których współczesny neoliberalny rynek pracy „nie potrzebuje”, nie chce, nie umie wykorzystać ich kwalifikacji do podnoszenia jakości wytwarzanych dóbr i usług, do poprawy warunków życia wszystkich. W zglobalizowanej neoliberalnej gospodarce liczy się wyłącznie doraźny, maksymalny zysk osiągany z nisko opłacanej pracy. Gospodarka neoliberalna nie kształtuje warunków rozwoju społecznego i ekonomicznego opartego na innych wartościach niż zysk; nie respektuje zasad i wartości ładu społecznego ukształtowanych w poprzednich pokoleniach. Nie jest zainteresowana wykorzystaniem wysokich i najwyższych kwalifikacji, gdyż praca najwyżej wykształconych (np. uczonych) nie zawsze przynosi doraźny i natychmiastowy zysk, lecz tworzy warunki do poprawy warunków życia w przyszłości. Nie jest zainteresowana kształtowaniem przyszłości, lecz osiąganiem „tu i teraz” najmniejszym kosztem, przy najniższych nakładach, największych zysków.

Pomimo wskazanych cech wspólnych wciąż nasuwa się pytanie, czy sytuację społeczną i ekonomiczną w sferze pracy i zatrudnienia na początku XXI wieku można porównywać $\mathrm{z}$ sytuacją sprzed dwóch wieków? Wiele wskazuje na to, że warunki współczesne zmieniły się istotnie: nie ma gwałtownie rozwijającego się przemysłu, który „pochłaniałby” wszelkie wolne zasoby pracy (łącznie z powszechną pracą kobiet i dzieci). Istnieją instytucje międzynarodowe i państwowe, obowiązuje prawo pracy i ochrona pracy, powszechne jest zabezpieczenie społeczne, a także prawa pracownicze i socjalne, działają związki zawodowe, prowadzony jest dialog społeczny. Zmieniła się sytuacja demograficzna; w wielu państwach Europy brakuje pracowników na rynku pracy, gdzie warunki pracy może określać - teoretycznie - pracownik, a nie pracodawca. Globalna gospodarka neoliberalna charakteryzuje się tym, że nie respektuje obowiązujących praw pracowniczych krajowych i międzynarodowych. Jej celem nie jest ochrona czy kształtowanie trwałego ładu społecznego, opartego na powszechnie akceptowanych wartościach. Ona poszukuje jedynie taniej pracy. Przenosi produkcję do tych części globu ziemskiego, gdzie nie obowiązują 
prawa pracownicze lub tam, gdzie władza miejscowa ich nie respektuje, a praca jest tania i pozostanie bardzo tania. Takich miejsc jest na świecie wciąż dużo, bo w wielu państwach nie powstały systemy polityki społecznej; nie ma w nich instytucji ochrony pracy pracowników. Także współcześnie w wielu państwach zachowano warunki do powstawania, rozwoju i utrzymywania się proletariatu (prekariatu), jako grupy pozbawionej podmiotowości i ochrony praw pracowniczych. Nie obowiązuje tam ochrona pracownika przez organizacje i instytucje państwowe, międzynarodowe czy związki zawodowe. Warunki do powstania prekariatu są także w państwach europejskich, które mają ugruntowane systemy ochrony pracowników. W takich państwach jak Polska czy w innych państwach europejskich - teoretycznie - nie ma prawnych możliwości powstawania prekariatu. Sytuacja w Europie, także w Polsce, jest nieporównywalna $\mathrm{z}$ sytuacją $\mathrm{w}$ wielu krajach pozaeuropejskich. W Polsce, podobnie, jak w państwach UE, w czasie gdy powstaje i rozwija się prekariat, istnieją liczne instytucje chroniące praw pracowników. Dlaczego zatem obowiązujące prawa nie obejmują ochroną wszystkich pracujących? Dlaczego - niezgodnie z obowiązującym prawem - część pracujących w Polsce „wyjęto spod prawa do ochrony”? Dlaczego taki stan zatrudnienia ukształtował się w końcu XX wieku także w Polsce? Dlaczego na początku XXI wieku nasze państwo i odpowiednie instytucje nie ingerują w położenie społeczne i ekonomiczne prekariatu, lecz przeciwnie, dopuszczają do powstawania warunków do rozwoju prekariatu?

Jeśli praca pozostaje współcześnie „kluczem do rozwiązywania kwestii społecznej", to czy praca na powrót stała się towarem? Analiza zjawisk i procesów dotyczących pracy i wynagrodzeń w Polsce w całym okresie transformacji podjętej w 1989 roku skłania do historycznych porównań. Sięgają one głęboko w przeszłość, do przełomu wieków XVIII i XIX, gdy państwo pozostawało „neutralne” wobec warunków i stosunków pracy, a mechanizmy „wolnego rynku" miały skutecznie rozwiązywać problemy społecz- 
ne. Współcześnie, mimo że od ponad dwóch wieków w pracach przedstawicieli różnych kierunków ideowych i politycznych pojawiały się analizy i programy stosowania innych niż wolnorynkowe narzędzi rozwiązywania problemów społecznych. W latach 90. XX wieku w różnych środowiskach powrócił, wydawało się dawno wyczerpany, temat debaty: czy państwo - szanujące zasady wolności gospodarczej - może uregulować ustawami warunki zatrudnienia, pracy i płac? Czy wystarcza samoregulacja i działanie rynkowych mechanizmów popytu i podaży? Dla wielu podmiotów życia publicznego od początku transformacji stawało się wiadome, że w Polsce narastają negatywne skutki gospodarki wolnorynkowej. Sygnalizowano, że odnawiająca się kwestia społeczna poważnie zagraża porządkowi społecznemu i gospodarczemu, pogłębiając oddalanie się od siebie wartości moralnych i wartości ekonomicznych. Mimo wielu ostrzeżeń polskie państwo długo broniło się przed ingerowaniem w mechanizmy wolnego rynku pracy. Przedsiębiorcy afirmowali zasady wolnego rynku, skutecznie wymuszali bierność państwa, nie akceptowali jego ingerencji, traktując pracę jak pospolity towar. Zasadą wynagradzania w Polsce w okresie transformacji stała się najniższa zapłata za pracę (na poziomie minimum przeżycia). Płaca miała wyrażać rynkową wartość pracy, a tej było na rynku stale w nadmiarze... Niskie wynagrodzenia uzasadniono powszechną dostępnością taniej „siły roboczej” i masowym bezrobociem. Bezrobocie w Polsce w okresie transformacji było skutkiem zlikwidowania ok. $5 \mathrm{mln}$ miejsc pracy. Niska płaca była uzasadniana też względami moralnymi; wyższe płace miały demoralizować pracowników i obniżać ich motywacje do pracy. Bezrobocie w Polsce, niskie płace oraz otwarte dla poszukujących pracy granice w krajach UE wywołały masową emigrację zarobkową młodego pokolenia Polaków. To, co rozpoczęło się w Polsce w okresie transformacji systemowej, pozostaje $\mathrm{w}$ sprzeczności z podejmowanymi działaniami organizacji międzynarodowych, w których Polska uczestniczy. 
Od początku lat 80 . XX wieku środowiska neoliberalne kwestionowały zasadność i racjonalność wszystkich praw pracowniczych ustanowionych w systemach społecznych w Europie w XIX i utrwalonych w XX wieku. Znaczną część zatrudnionych wyłączono z podlegania utrwalonym i powszechnie stosowanym prawom ochrony pracowników. Negowanie praw pracowniczych rozpoczęło się od wysuwania twierdzenia, że prawa te zostały nabyte „niesłusznie”, są szkodliwe dla swobodnego rozwoju gospodarki wolnorynkowej, gdyż niszczą wolność gospodarczą ${ }^{20}$. Wraz z nasilającą się krytyką utrwalającą pogląd o bezzasadności utrzymywania wielu praw pracowniczych i socjalnych powiązanych z pracą nastąpił rozstrój systemu pracy i zatrudnienia. Nasilający się nacisk na unieważnienie w stosunkach pracy praw pracowników ustanowionych i wywalczonych w przeszłości - skutkował odstępowaniem od zasady podmiotowości pracownika, poszanowania jego godności, kwestionowaniem praw pracownika i jego zobowiązań wobec rodziny. Wprowadzane zmiany to istotne przyczyny powstawania w końcu XX wieku prekariatu. Na przełomie wieków XX i XXI powstała (nie wiadomo: stworzona przypadkiem czy celowo?) liczna „rezerwowa” armia osób zdolnych do pracy, lecz pozbawionych podstawowych zdobyczy socjalnych, jakimi były do niedawna trwałe zatrudnienie oraz powiązane z nim ubezpieczenie społeczne i gwarancje socjalne. Pojawienie się licznej grupy osób stale zagrożonych utratą elementarnych środków do życia nastąpiło wskutek nacisku globalnych pracodawców na rozwijanie tzw. „elastycznych” form zatrudnienia i otwartego coraz szerzej - pozbawianego regulacji prawnych - „elastycznego” zatrudnienia i rynku pracy ${ }^{21}$.

20 „Wmawianie politykom, że rynek jest najlepszym regulatorem procesów ekonomicznych, to szkodliwe nadużycie intelektualne, a wręcz zwykłe oszustwo". Por.: J. Oleński, Uwarunkowania infrastrukturalne rynku pracy w Polsce, w: Praca i płaca. Państwo i rynek, red. J. Hrynkiewicz, Warszawa 2014, s. 97nn.

${ }^{21}$ W. Rutkowski, Współczesne państwo dobrobytu. Ekspansja, kryzys, spory, Warszawa 2009. 
Wskutek szybkiego rozwoju neoliberalnej globalnej gospodarki powstaje „globalna struktura społeczna”, w której coraz większy udział mają grupy (warstwy?) trwale i czasowo bezrobotnych, "elastycznie" zatrudnianych, wynajmowanych od pośredników do pracy na czas określony, coraz gorzej dostosowujących się do gwałtownie zmieniających się warunków pracy i życia. Zatroskanych o swój byt codzienny, zaabsorbowanych walką o przetrwanie, żyjących na marginesie społeczeństwa, wykluczonych, wyizolowanych ze społeczności lokalnych. Słowo „prekariat” określa grupy pracowników skazanych na nieustającą niepewność jutra we wszystkich wymiarach ich życia z powodu pozbawienia ich stałej pracy i dochodu. Powstanie prekariatu to skutek postępującej deformacji procesu pracy wskutek otwartego kwestionowania przez środowiska neoliberalne podmiotowych i ludzkich (godnościowych) wymiarów pracy.

Odstąpienie od podmiotowości pracy uzasadnia się wolnością jako naczelną wartością konstytuującą współczesne społeczeństwa, w tym przypadku wolnością działalności gospodarczej i wolnością wyboru pracy. Wolność wyboru pracy jest istotną zasadą kształtowania stosunków pracy. Jednak w sytuacji braku lub ograniczonego wyboru pracy staje się pustym hasłem. Wolność pracy to wygodne uzasadnienie odejścia od zatrudniania na podstawie umowy o pracę. Pozwala pracodawcy na odstąpienie od zatrudnienia, chroniącego pracownika przed degradacją zawodową. Pozbawienie, pracownika, szczególnie młodego, stałej pracy to jednocześnie odebranie mu możliwości rozwoju, zdobywania wyższych kwalifikacji, awansu zawodowego i ekonomicznego. Większość młodego pokolenia podejmującego pracę jest do tego zmuszona koniecznością uzyskania środków utrzymania; przyjmuje pracę na warunkach określonych przez pracodawcę. Wolności pracy nie ma tym bardziej, im trudniejsza jest sytuacja materialna rodziny, im bardziej pracownik musi zdobyć i dostarczyć rodzinie środki utrzymania.

Jakie są przyczyny odejścia od norm i zasad wypracowanych i stosowanych w polityce społecznej państwa w wiekach XIX i XX? 
Obserwacja zmian w zatrudnieniu w Polsce w ostatnich trzech dekadach pokazuje ewolucję form zatrudnienia od umowy o pracę do upowszechniających się form zatrudnienia niestałego: zlecenia zadania do wykonania, umowy na czas określony, umowy o dzieło, samozatrudnienia, „wypożyczania” pracownika, doraźnego zatrudniania „na telefon”, a także zatrudniania na „czarno”, bez zawierania jakiejkolwiek pisemnej umowy ${ }^{22}$. Dla większości osób młodych podejmujących pracę cechą charakterystyczną współczesnych stosunków pracy jest brak stałego zatrudnienia. W przekonaniu wielu pracodawców korzystną dla nich formą zatrudnienia jest ta forma, która zwalnia pracodawcę z jakichkolwiek zobowiązań wobec pracownika. Najkorzystniej byłoby, gdyby potencjalny pracownik pozostawał w nieustającej gotowości do przyjęcia zatrudnienia, a potencjalny pracodawca mógłby „wzywać” go do wykonania określonego zadania wtedy, gdy pojawi się taka potrzeba, i oddalać bez jakichkolwiek zobowiązań. Formy niestałego i niestabilnego zatrudnienia dotyczą głównie ludzi młodych, absolwentów szkół różnych poziomów i typów. Niestała praca poza brakiem bezpieczeństwa socjalnego, związanego z niepewnością posiadania względnie stałego dochodu, nie zapewnia ubezpieczenia społecznego w razie zdarzenia losowego (np. choroby), które uniemożliwia zarobkowanie. Dlatego stałe zatrudnienie jest szczególnie ważne dla osób odpowiedzialnych za byt rodziny. Pracodawcy niechętnie zatrudniają na stałe; pracownik zatrudniany doraźnie, „na telefon”, „na zlecenie” itp., nie przysparza im kosztów związanych ze stałą pracą i ubezpieczeniem. Pracownik pozbawiony ubezpieczenia społecznego nie nabywa prawa do świadczeń w razie choroby, urodzenia dziecka, opieki nad dzieckiem, inwalidztwa, wypadku w pracy, śmierci, starości itd. W razie zdarzenia losowego nie zapewni rodzinie środków utrzymania - sam może stać się „ciężarem” dla rodziny pozbawionej dochodu i środków utrzymywania.

${ }^{22}$ Por. E. Giermanowska, Ryzyko elastyczności czy elastyczność ryzyka. Instytucjonalna analiza kontraktów zatrudnienia, Warszawa 2013. 
W koncepcji globalnej neoliberalnej gospodarki ubezpieczenie społeczne nie ma charakteru społecznego; dlatego w coraz mniejszym stopniu ma ono zależeć od zbiorowej solidarności i odpowiedzialności pracodawcy i państwa, a w coraz wyższym stopniu ma być przedmiotem indywidualnej przezorności i samo-zaradności oraz zależeć od sprawności działania kapitałowych instytucji ubezpieczających na zasadach komercyjnych. Wskutek zatrudnienia na wszelkiego rodzaju kontraktach „śmieciowych” pozbawia się pracownika ochrony pracy; instytucje ochrony pracy przestają chronić prawa i zdrowie pracownika, wartości jego życia pozazawodowego, praw rodziny pracownika i jego podmiotowość. Pracownik „śmieciowy" pozbawiony jest też solidarnej ochrony ze strony związku zawodowego, gdyż pracownicy zatrudnieni na umowach „śmieciowych" na ogół nie uczestniczą w związku zawodowym pracowników i nie korzystają z jego ochronnych działań.

Zmiany w stosunkach i warunkach pracy, za sprawą koncepcji neoliberalnych w globalnej gospodarce, mają wymiar nie tylko ekonomiczny, choć ten jest najczęściej eksponowany przez pracodawców, głównych beneficjentów tych zmian. Obniżenie kosztów pracy skutkuje dużymi korzyściami finansowymi dla pracodawcy. Skuteczny nacisk kręgów neoliberalnych na zaniechanie stosowania w zatrudnieniu umów o pracę, prawa i ochrony pracy, ubezpieczenia społecznego, uczestnictwa w solidarnym ruchu związkowym pracowników ma rozległe konsekwencje. Przejawiają się one w kształtowaniu stosunków pracy, warunków życia pracownika i jego rodziny, utrzymywaniu więzi społecznych, kształtowaniu dążeń, aspiracji i ambicji, poczuciu wartości, przynależności i odpowiedzialności. Dla państwa i pracownika brak stałej umowy o pracę skutkuje rozległymi negatywnymi konsekwencjami. Ogólnie proces ten powoduje przeniesienie przez przedsiębiorcę kosztów ryzyka działalności gospodarczej na pracownika, w konsekwencji na państwo, na ogół obywateli opłacających daniny publiczne. Korzyści ze stosowania umów „śmieciowych” czerpie przedsiębiorca. 
Konsekwencje braku zagwarantowanych praw pracowniczych ponoszą głównie pracownik i jego rodzina. Państwo ulegając żądaniom przedsiębiorców, odmawiając pracownikom ochrony ich praw, ostatecznie ponosi tego konsekwencje; obowiązek dostarczenia środków utrzymania osobom, które nie uzyskają ich samodzielnie, w ostateczności spoczywa na państwie. Praca, dochody z pracy są podstawą bytu ekonomicznego rodziny. Pozbawienie pracowników prawa do stałego wynagrodzenia za pracę i do ubezpieczenia ma rozległe negatywne skutki dla procesów demograficznych, dla powstawania i rozwoju rodziny. Brak stałego zatrudnienia, przewidywalnego wynagrodzenia, możliwości doskonalenia w zawodzie i osiągania wyższego poziomu dochodów, a także brak ubezpieczenia w razie zdarzenia losowego stanowią poważną przeszkodę w podejmowaniu decyzji o założeniu i powiększeniu rodziny. Narastający kryzys demograficzny w większości państw europejskich ma swoje źródło w pogłębiających się procesach, które obejmują system pracy.

Praca i dochody z pracy to ważne czynniki kształtujące strukturę społeczną, wyznaczające miejsce jednostki w społecznym podziale pracy i jej udział w dochodach ${ }^{23}$. Zmiany w zatrudnieniu i usytuowaniu pracy w globalizującej się neoliberalnej gospodarce prowadzą do fragmentacji struktury społecznej, pogłębiania się nierówności społecznych, powstawania coraz liczniejszych grup społecznych żyjących w trudnych warunkach materialnych (nierzadko w ubóstwie), bez szans na zmianę swojego położenia ekonomicznego i społecznego. Neoliberalna gospodarka, dążąc do maksymalizacji zysku przez obniżanie wynagrodzeń pracowników, pozbawiając ich bezpieczeństwa socjalnego (trwałości zatrudnienia i ubezpieczeń), w konsekwencji prowadzi do coraz większej koncentracji zysku, pozostającego do dyspozycji nielicznych. Powszechną praktyką neoliberalnej gospodarki jest deprecjono-

${ }^{23}$ H. Domański, Wymiary stratyfikacji i hierarchie społeczne, w: Polska na przełomie XX i XXI wieku, red. M. Marody, Warszawa 2007. 
wanie wysiłku i kosztu uzyskania kwalifikacji zawodowych, gdyż w wielu, a zasadniczo w większości wykonywanych prac „śmieciowych" przestały one mieć znaczenie dla pracodawcy. Z obniżeniem wartości kwalifikacji związany jest m.in. proces tzw. deregulacji zawodów. W Polsce odbywa się to pod pozornie słusznym hasłem „otwierania młodym generacjom” szerokiego dostępu do wielu zawodów. Samo hasło - otwierania zawodów dla młodego pokolenia - jest zasadne, bo musi następować naturalna wymiana pokoleń w poszczególnych zawodach. Dostęp do zawodu powinien jednak być możliwy dopiero po uzyskaniu wymaganych $\mathrm{w}$ danym zawodzie kwalifikacji, bez nich obniża się standard, poziom i jakość pracy w zawodzie. W wyniku m.in. procesów „deregulacji” do skomplikowanych zadań zawodowych powoływane są osoby bez odpowiednich kwalifikacji. Praktyka ta pozwala upowszechniać zamianę umownych stosunków pracy; szczególnie osobom młodym, wchodzącym na rynek pracy, na „umowy” określane jako elastyczne (tzn. „śmieciowe”), które pozbawiają pracownika trwałości zatrudnienia, stabilizacji, możliwości rozwoju zawodowego, doskonalenia kwalifikacji i awansu zawodowego. Umowa „śmieciowa” zwalnia pracodawców z jakichkolwiek zobowiązań wobec pracownika i jego rodziny. Praca traktowana jest jak pospolity „towar”, którego cenę ma wyznaczać wolny rynek, co oznacza niskie wynagrodzenie, bez związku z wartością i jakością pracy, kosztami nabycia i doskonalenia kwalifikacji. Wynagrodzenie nie ma związku z kosztami utrzymania pracownika i rodziny (jest dalekie od koncepcji Adama Smitha wynagrodzenia wiązanego z kosztem utrzymania i wychowania następcy). Pracownik „śmieciowy” z zasady nie ma ubezpieczenia społecznego od zdarzeń losowych; w razie zdarzenia staje się „klientem” prywatnej lub państwowej „dobroczynności”.

Umowa „śmieciowa” nie daje pracownikowi „śmieciowemu” szans na dalsze kształcenie zawodowe, zdobywanie kwalifikacji, awans w zawodzie. Osobom młodym, które po ukończeniu szkoły nie nabyły kwalifikacji zawodowych i zatrudniły się na umowach 
„śmieciowych”, grozi trwałe pozostawanie bez kwalifikacji i stabilizacji zawodowej. Będą one powiększały „rezerwuar” wolnych zasobów pracy, używany do łatwego zatrudniania za najniższe wynagrodzenie na umowach „śmieciowych”. To z nich ukształtują się coraz liczniejsze grupy „biednych pracujących” (w literaturze angielskiej working poor). To także ci, którzy nie są bezrobotni, ponieważ pracują, lecz ich praca nie daje im dostatecznych do utrzymania siebie i rodziny środków, dlatego coraz częściej stają się klientami pomocy społecznej lub organizacji charytatywnych. Nie są bezrobotni, nie są niepełnosprawni czy niezaradni, ale system neoliberalnego wyzysku spycha ich na poziom tak niskich dochodów, że zmuszeni są do poszukiwania „wsparcia” od instytucji pomocy społecznej lub osób prywatnych. Skutkiem stosowania w zatrudnianiu młodych pracowników tzw. umów śmieciowych jest szybka i nieodwracalna degradacja kapitału ludzkiego i potencjału zawodowego, jaki młody człowiek uzyskuje podczas nauki szkolnej przed podjęciem pracy. Utrwalony w praktyce zatrudnienia sposób postępowania pracodawców wobec młodych pracowników staje się "prostą drogą" do powstawania i rozwoju prekariatu ${ }^{24}$.

Prekariuszy charakteryzuje wiele wspólnych cech: brak doświadczenia zawodowego, ograniczone doświadczenie życiowe, brak samodzielności ekonomicznej, ograniczona, a wskutek braku pracy i kwalifikacji zawodowych malejąca szansa na trwałe zatrudnienie i zdobycie kwalifikacji, co dla młodej osoby mogłoby się stać celem i sensem pracy oraz kierunkiem rozwoju zawodowego. Wymienione cechy położenia prekariuszy nie stwarzają jasnej perspektywy stabilnego życia zawodowego oraz stabilizacji życiowej i rodzinnej. Brak perspektywy trwałego zatrudnienia i uzyskania kwalifikacji do stałej pracy to także brak ochrony przez stresem, odrzuceniem, degradacją społeczną i ubóstwem

${ }^{24}$ Por. Zatrudnienie na czas określony w polskiej gospodarce. Społeczne i ekonomiczne konsekwencje zjawiska, red. M. Bednarski, K. Frieske, Warszawa 2012. 
oraz wykluczeniem społecznym. Niska ochrona młodego pracownika zatrudnionego na umowę śmieciową (lub całkowity jej brak) prowadzi do utrwalenia i poszerzania segmentacji rynku pracy. Skazuje znaczną część wchodzącej na rynek pracy generacji - już na początku kariery pracowniczej - na stale niepewną, doraźną pracę i niestały dochód. Rodzi poczucie coraz większego zagrożenia utratą możliwości uzyskania kwalifikacji zawodowych oraz względnie stałego zatrudnienia. Umowy terminowe nie pełnią dawnych funkcji sprawdzeniu potencjalnych możliwości zawodowych młodego pracownika. Nie służą zdobywaniu doświadczenia, poznaniu treści pracy, nabywaniu umiejętności, adaptacji w miejscu pracy i docelowemu przekształceniu umowy terminowej na stałe zatrudnienie. Zdecydowana większość umów terminowych pozostanie na zawsze terminowa; nie przekształcą się one w umowy stałe, nie doprowadzą do uzyskania lepiej wynagradzanej pracy. Nie stanowią etapu zatrudnienia, które jest czasem zdobywania doświadczenia i kwalifikacji zawodowych, wyboru najbardziej odpowiadającego zdolnościom miejsca i charakteru pracy. Dla młodych pracowników umowy „śmieciowe” stają się swoistą pułapką zawodową: w przypadku większości umowa terminowa będzie przerywana okresami krótszego lub dłuższego bezrobocia, a czas bezrobocia będzie utrwalał niepewne położenie, bez nadziei na trwałą zmianę sytuacji nie tylko zawodowej, ale także społecznej i rodzinnej; nie tylko sytuacji własnej, ale także następnego pokolenia $\mathrm{w}$ rodzinie.

Reakcja podmiotów polityki społecznej na pojawienie się nowej, coraz liczniejszej grupy społecznej nigdy nie zmierzała do usunięcia istotnych przyczyn powstawania coraz liczniejszego prekariatu. Przeciwnie - współczesna polityka społeczna zaakceptowała wzrost liczebny prekariatu i problemy społeczne, jakie są skutkiem pojawienia się i szybkiego wzrostu liczebnego prekariuszy. W realizowanych podejściach do narastających problemów społecznych, wynikających z istnienia prekariatu, podejmuje działania utrwalające jego istnienie i dostosowanie do powstałej sytuacji. 
Generalny kierunek działań skierowany jest na to, aby uzyskać akceptację sytuacji przez prekariuszy i adaptować ich do pozycji społecznej i warunków, w jakich mają żyć i pracować. Różne podmioty polityki społecznej prowadzą liczne projekty, a w ich ramach nieustające szkolenia, aby prekariusze stale byli kategorią zatrudnialną, zwłaszcza że być może będą potrzebni neoliberalnej globalnej gospodarce. Współczesna „projektowa” polityka społeczna oferuje prekariuszom stałą socjalizację, nieustająco dostosowuje ich do „nowych”, zmieniających się warunków globalnej gospodarki. Okazuje im stałą ,troskę”, gdyż prekariusze łatwo się alienują i tracą konieczne więzi społeczne, dlatego stałą troską jest „zadbanie” o ich ponowne zintegrowanie ze społeczeństwem. Ich nieokreślony status i nieustanne poczucie zagrożenia z powodu sytuacji, w jakiej żyją, wymaga stworzenia specjalnych rozwiązań systemowych. Specjalnie dla prekariuszy wiele państw Unii Europejskiej, także Polska, stworzyło liczne instytucje „opieki” i nieustannego szkolenia. Prekariusze kwalifikowani są przez „specjalistów” do właściwych kategorii, poddawani terapii, zabiegom szkoleniowo-terapeutycznym, aby pozostawali wciąż „elastyczni” wobec rynku pracy oraz nieustająco zdolni sprostać nowym wymaganiom i zmiennym warunkom. Szkoleni są też po to, aby poznali i zaakceptowali właściwe prekariuszom miejsce w społeczeństwie. To dla nich państwowe i „przyrządowe”, rynkowe i „pararynkowe” organizacje tworzą liczne projekty aktywizujące do gotowości do pracy, rozdają lub zabierają im „przywileje", finansują, programują, analizują, oceniają, realizują i rozliczają liczne (europejskie) projekty. W tzw. „pobudzaniu” aktywności na rynku pracy osób wykluczonych ze stałego zatrudnienia chodzi o utrzymywanie samonapędzającego się mechanizmu nieustającej „adaptacji” i poprawianie poziomu zatrudnialności tych, których systemowo pozbawiono: stałej pracy, możliwości rozwoju i awansu zawodowego oraz zabezpieczenia społecznego, które winno im gwarantować rzeczywistą wolność obywatelską (wolność od zagrożenia ubóstwem). 
Wielki wysiłek przystosowawczy prekariuszy, ich uczestnictwo w niekończących się szkoleniach jest finansowany ze źródeł publicznych, za pośrednictwem licznych organizacji pobierających na utrzymanie duże środki publiczne. Udział prekariuszy w zajęciach terapeutycznych i szkoleniowych ma służyć stałemu uzasadnianiu istnienia licznych organizacji pośredniczących w wydawaniu publicznych środków. Ma też uzasadniać poważne wydatki publiczne na istnienie rozrastającej się biurokracji „pozarządowej”, „obsługującej” prekariuszy. W programach aktywizowania prekariuszy (nazywanych "podopiecznymi” lub „klientami”) traktuje się ich przedmiotowo, gdyż wymagają oni nieustającej, troskliwej, z zarazem surowej postawy „specjalistów”. Będąc „klientami” licznych organizacji finansowanych ze źródeł publicznych, prekariusze nie zasługują na podmiotowe traktowanie, ponieważ wymagają stałej troski, nie są samodzielni w swym trudnym położeniu społecznym i materialnym, nie mogą być zatem traktowani podmiotowo. Gdyby prekariusze byli traktowani podmiotowo, wówczas mieliby ustalone (lub nadane) prawa, mogliby też o te prawa się upominać. Jeśli jednak są oni przedmiotem nieustającej „troski”, jeśli absorbują swoim nieuzasadnionym istnieniem wiele organizacji, którym państwo dostarcza obfitych środków na sprawowanie nad nimi opieki, to staje się oczywiste, że prekariusze nigdy nie mieli i nigdy nie mogą, nie powinni mieć praw.

Aktywność publicznych instytucji polityki społecznej wobec prekariuszy skierowana jest na nieustające działania integracyjne, szkoleniowe i adaptujące do społeczeństwa i nieznanych potrzeb rynku pracy. Celem działań szkoleniowo-aktywizujących i integracyjno-przystosowawczych jest wyłącznie "łagodzenie” skutków poszerzającego się i pogłębiającego wykluczenia społecznego prekariuszy. Działania, na które przeznacza się obfite środki publiczne, nie rozwiązują narastającego problemu społecznego, ponieważ nie usuwają przyczyn, które tkwią w ekspansji neoliberalnej globalnej gospodarki, uległości słabego państwa oraz podporządkowanej państwu polityce społecznej. Dlatego 
działania licznych organizacji i instytucji zaopatrywanych w obfite środki publiczne skierowane są nie do „sprawców”, to jest na procesy systemowego utrwalania nierówności i społecznego wykluczenia osób i grup słabszych, lecz na „ofiary” systemu neoliberalnej gospodarki globalnej.

Pozbawienie pracowników praw oraz ochrony i bezpieczeństwa na rynku pracy ma rozległe skutki. Nie ma badań naukowych, które pozwoliłyby udzielić odpowiedzi na wiele ważnych pytań. Jakie procesy spowodowały stan, w którym pracownik utracił prawo do: ochrony pracy, wynagrodzenia za pracę, bezpieczeństwa w pracy, a także odszkodowania za wypadek w pracy, zasiłku w razie choroby, lub innych zdarzeń losowych? Dlaczego pracownik utracił prawo do awansu, nauki zawodu i szkolenia, uzyskania godziwej zapłaty za pracę i dochodu wystarczającego na utrzymanie własne i rodziny, do podwyżki wynagrodzenia w związku ze wzrostem kosztów utrzymania, do ochrony przed natychmiastowym zwolnieniem? Czy też w ogóle utracił prawo do zapłaty za pracę? Jak to się stało, że pracowników „śmieciowych" faktycznie pozbawiono prawa do protestów, do reprezentacji ich interesów, do strajku, ochrony związkowej, dialogu w środowisku pracy? Dlaczego nie działają formalnie obowiązujące przepisy dotyczące praw pracowniczych (prawa międzynarodowego, które Polska ratyfikowała, prawa krajowego; konstytucji RP, kodeksy, ustawy)? Czym wyjaśnić ograniczoną działalność i bierność instytucji gwarantujących zatrudnionym bezpieczeństwo i ochronę? Dlaczego następuje likwidacja systemowych „hamulców bezpieczeństwa”, które, jeszcze przed kilkunastu laty dotyczyły niemal ogółu zatrudnionych i wszystkich sfer życia społecznego? Następuje likwidacja rozwiązań chroniących przed ubóstwem w razie niezdolności do pracy z powodu choroby, podeszłego wieku, inwalidztwa, czy trudnej sytuacji rodzinnej. Instytucje ubezpieczenia społecznego oddziela się od systemu zatrudnienia przekształcając je w instytucje do osiągania coraz wyższych zysków. W ubezpieczeniu społecznym np. odstępuje się od celów społecznych, które pierwotnie 
uzasadniały ich powołanie. Coraz częściej wskazuje się, że nie ochrona ludzi starych przed skrajnym ubóstwem ma uzasadnić istnienie społecznego systemu ubezpieczenia emerytalnego, lecz zyski finansowe, jakie ubezpieczenia emerytalne mają wygenerować dla firm ubezpieczeniowych i finansowych, na „ważne”, choć nieokreślone ich własne cele. To nie dbałość o stan zdrowia społeczeństwa uzasadnia w Polsce istnienie instytucji ochrony zdrowia, lecz osiąganie przez tę instytucję najwyższych zysków - dodajmy zysków generowanych przez instytucje utworzone i utrzymywane ze środków pochodzących z przymusowej daniny publicznej wszystkich obywateli uzyskujących dochody. Państwowy Fundusz Rehabilitacji Osób Niepełnosprawnych ma generować zyski, bo przekształcił się w instytucję biznesową. Przemiany prywatyzacyjne (uwłaszczeniowe, zawłaszczeniowe) w sferze ważnych usług cywilizacyjnych: ochrony zdrowia, edukacji, kultury, bezpieczeństwa socjalnego i społecznego, nie podnoszą standardu życia obywateli. Przeciwne, wykluczają najuboższych obywateli z dostępu do tych usług, a uboższej części społeczeństwa ograniczają dostęp, powiększając społeczne nierówności ${ }^{25}$.

W ostatnich dekadach XX wieku rozpoczął się proces odchodzenia od polityki społecznej uprawianej bezpośrednio przez państwo na rzecz zlecania zadań państwa organizacjom. Zadania państwa zamieniono na projekty, które przekazuje się do realizacji organizacjom. Mają one z założenia „lepiej i skuteczniej” rozwiązywać problemy społeczne. Odstępowanie państwa od realizowania zadań społecznych uzasadnia się stosowaniem zasady subsydiarności: państwo nie powinno wyręczać mniejszych podmiotów (np. rodziny, społeczności lokalnych) w wypełnianiu ich zadań. Państwo nie powinno odbierać mniejszym podmiotom zadań, które są one zdolne wypełniać samodzielnie. Subsydiarność jako

25 Statystyki wskazują, że nierówności w dostępie do usług cywilizacyjnych (zdrowie, edukacja, kultura, wypoczynek, rekreacja, zajęcia dodatkowe) uwarunkowane są poziomem dochodów rodzin, wykształceniem rodziców oraz miejscem zamieszkania. 
ważna zasada kształtowania ładu społecznego ma budować i umacniać podmiotowość małych grup społecznych. Zastosowanie zasady pomocniczości jest ze wszech miar korzystne; w życiu społecznym kształtuje ona tożsamość, podmiotowość i odpowiedzialność obywateli za „bieg spraw publicznych”, za te wartości dobra wspólnego, które są dobrem wszystkich obywateli ${ }^{26}$. Stosowanie zasady subsydiarności przynosi korzyści wówczas, gdy podstawą polityki społecznej państwa są rozwinięte, ugruntowane i utrwalone logiczne i skutecznie działające systemy społeczne (np. pracy i zatrudnienia). Tylko wówczas mniejsze podmioty mają stworzone odpowiednie warunki do realizacji przekazanych im przez państwo zadań i racjonalnego użycia środków publicznych. Jeśli jednak podstawowe warunki stosowania zasady pomocniczości nie są spełnione, gdy polityka społeczna państwa nie rozwiązała systemowo generalnych problemów społecznych: bezrobocia, ubóstwa, wykluczenia grup słabszych, to zastosowana "projektowa” metoda polityki społecznej prowadzi do pojawienia się nowej kwestii społecznej jako skutku nierozwiązanych systemowo problemów: pracy, bezrobocia, niskiego wynagrodzenia, przedmiotowego traktowania pracowników i ich pracy. Państwo rozpraszając środki na projekty, rezygnuje z korzystania z narzędzi właściwych i dostępnych tylko państwu, jak budowanie i utrwalanie systemów skutecznie likwidujących przyczyny i rozwiązujących problemy. Mistyfikując zasadę subsydiarności przez „społeczną politykę projektową”, państwo nie buduje systemów, rozprasza środki, ucieka od odpowiedzialności za rozwiązywanie problemów społecznych. Przerzuca odpowiedzialność za narastające skutki nierozwiązanych problemów na wykonawców projektów lub rodziny, grupy dotknięte skutkami tych problemów (które są nierozwiązywalne przez projekty). Projekty tworzone daleko od rzeczywistych problemów nie tylko nie rozwiązują żadnego z ważnych problemów społecznych,

${ }^{26}$ J. Ratzinger, Prawda, wartości, władza. Kiedy państwo można uznać za pluralistyczne, tł. G. Sowinski, Kraków 1999, s. 82. 
lecz rodzą nowe patologie funkcjonalne, pomnażają negatywne skutki niewydolności państwa. Realizując społeczną politykę „projektową", państwo utrwala patologicznie i chaotycznie tworzone funkcje, m.in. w zakresie podziału dochodu, ochrony zatrudnienia i wynagrodzenia za pracę, ubezpieczeń społecznych, ochrony zdrowia, kryzysowej sytuacji ludnościowej (niska stopa urodzeń, masowa emigracja zarobkowa). Państwo skupia wysiłek na rozdawaniu środków i kontroli (formalnej, nie merytorycznej) realizowania projektów, nie rozwiązuje żadnego problemu i pozbywa się odpowiedzialności za wciąż niezbywalne zadania w sferze kształtowania ładu społecznego, z których nie może być ani zwolnione (ani zastąpione) $)^{27}$.

Podstawowym źródłem współczesnej kwestii społecznej jest globalna gospodarka neoliberalna, która wciąż poszukuje w świecie najtańszego pracownika, aby powiększać zyski. Wymusza ona na państwach słabych ekonomicznie i politycznie korzystne dla siebie warunki działania, polegające na odstąpieniu od: obowiązujących zasad zatrudnienia, ubezpieczenia społecznego, płacenia podatków, wnoszenia opłat na rzecz środowiska. W zamian za uzyskiwane od rządów korzyści oferuje miejsca pracy, zatrudniając najczęściej za najniższe wynagrodzenie, ograniczając płace pracowników do minimum życiowego. Tak następuje przerzucenie części kosztów oraz całości skutków ryzyka gospodarczego przejawiającego się m.in. cyklicznymi kryzysami w gospodarce rynkowej - na pracujących i państwo. Reguły stosowane przez neoliberalną globalną gospodarkę $\mathrm{w}$ istocie odwracają zasady gospodarki rynkowej; to nie przedsiębiorca ma zmierzyć się ze

${ }^{27}$ Przykładem braku systemowych rozwiązań we współczesnej Polsce jest proceder odbierania rodzicom dzieci z powodu ubóstwa rodzin. Przyczyny ubóstwa rodzin mają charakter systemowy i obiektywny - niskie płace, choroba i brak ubezpieczenia. Gdy rodzina nie może samodzielnie wypełnić funkcji ekonomicznych, staje się przedmiotem wrogiego działania instytucji publicznych, które udzielając rodzinie pomocy - niszczą jej podmiotowość, a w skrajnych przypadkach, ingerując w jej funkcje i strukturę, niszczą ją. 
skutkami kryzysu gospodarczego, lecz pracownik, którego można łatwo zwolnić i jeszcze łatwiej zatrudnić, pozbawić ubezpieczenia społecznego, obniżyć płacę, wynająć jego pracę przez agencję zatrudnienia. Brak ochrony i bezpieczeństwa zatrudnienia, niskie wynagrodzenia, tzw. elastyczne zatrudnienie, niskie koszty działalności gospodarczej to zasadnicze cechy globalnej gospodarki neoliberalnej.

Współczesna kwestia społeczna wyraża się m.in. powstaniem prekariatu. Prekariusze to głównie młode pokolenia na rynku pracy. Z analizy sytuacji młodzieży na rynku pracy w Polsce w 2014 roku (w dwóch grupach wieku: 15/18 - 24 lata i 25-34 lata) wynika, że wymienione grupy wiekowe w stosunku do grup starszych wyróżniają się na rynku pracy: ponad dwukrotnie wyższą stopą bezrobocia oraz znacznie dłuższym okresem jego trwania; wysokim odsetkiem zatrudnianych na podstawie nietypowych umów o pracę, nazywanych śmieciowymi; pracą na umowę o dzieło, umowę zlecenie, na czas określony, w niepełnym wymiarze pracy; zatrudnianiem „na telefon”, do wykonania zadania, organizowanym przez agencje zatrudnienia; niskim wynagrodzeniem za pracę, traktowanym jako standard wynagrodzenia; wyłączeniem młodych pracowników (tzw. czasowych) z polityki kadrowej firmy, a także z kształcenia, dokształcania, szkolenia, oceniania, awansowania, podnoszenia płac, nagradzania itp.; zaniechaniem naturalnej dla kształtowania kapitału ludzkiego sekwencji w zatrudnieniu (nauka szkolna, staż zawodowy, praca $\mathrm{w}$ zawodzie, szkolenie i doskonalenie zawodowe, awansowanie w zawodzie, osiąganie biegłości i doskonałości w pracy zawodowej, nabywanie specjalizacji i uprawnień, stałe podnoszenie poziomu wynagradzania).

Istotna część młodego pokolenia Polaków dotknięta jest jednocześnie potrójnym stanem bierności: nie uczy się, nie pracuje, nie zdobywa doświadczenia zawodowego. Rozległe skutki postępującej tzw. segmentacji rynku pracy obejmują kolejne młode generacje. 
Z powodu niskiego poziomu inwestowania w kapitał ludzki gospodarka osiąga niski wzrost gospodarczy (tzw. pułapka niskiego czy średniego rozwoju). Nakłady na kapitał ludzki są w Polsce nie tylko niskie, są także marnotrawione. Młode pokolenie w zdecydowanej większości opuszcza system szkolny z bardzo niskim wykształceniem, bez wiedzy i umiejętności dalszego kształcenia się. Młodzież nie nauczy się zawodu na różnych pozaszkolnych formach kształcenia, jeśli nie wyniesie z nauki szkolnej przygotowania do zdobywania wiedzy. Przeznaczanie środków publicznych na różnego rodzaju bezsensowne szkolenia (prowadzone przez stowarzyszenia, fundacje, OHP i podobne formy), a nie na solidne kształcenie w szkołach, powoduje podwójne marnotrawstwo: publicznych środków finansowych oraz szans młodzieży na uzyskanie kwalifikacji. Długotrwałe niepewne zatrudnienie rodzi dalsze negatywne skutki społeczne: krótsze lub dłuższe bezrobocie, brak szans na zmianę położenia, niskie dochody z pracy, a z upływem lat ograniczenie możliwości nabywania kwalifikacji i zmiany sytuacji.

Skutki rozstroju systemu pracy są najdotkliwsze dla młodego pokolenia wstępującego w dorosłe życie. Są to: niepewność pracy i dochodu, powtarzające się i wydłużające okresy bezrobocia, małe prawdopodobieństwo zmiany położenia zawodowego i ekonomicznego, opóźnienie lub zaniechanie założenia rodziny. Nawet gdy nieliczni znajdą stałe zatrudnienie, to jest to praca nisko płatna, która w konsekwencji skazuje ich rodziny na ubóstwo i wykluczenie społeczne. Dla młodych rodzin wykluczenie i ubóstwo stają się współcześnie znacznie większym zagrożeniem niż dla starszych generacji. Ubóstwo i wykluczenie, do którego prowadzą bezrobocie i czasowe zatrudnienie, niskie wynagrodzenie, brak kwalifikacji, oznaczają dla społeczeństwa utratę tych wartości, które nie zostały wytworzone przez bezrobotnych.

Czy na te groźne społecznie zjawiska nie było reakcji podmiotów odpowiedzialnych za kształtowanie ładu społecznego? Przeciwnie, UE wydała w tej sprawie ok. 15 raportów. Jednak 
raporty nie rozwiązują problemów społecznych. W Polsce po 14 latach transformacji poziom bezrobocia osiągnął w 2002 roku 21,2 proc., a wskaźnik zatrudnienia wynosił 43,3 proc. $^{28}$. Jednak reakcji na ten stan nie było. W 2011 roku bezrobocie osiągnęło 13 proc., a wskaźnik zatrudnienia 46,3 proc.. Reakcji polityki społecznej państwa też nie było. Bezrobocie młodzieży w każdym $z$ wymienionych przypadków było dwukrotnie wyższe ${ }^{29}$. Nie zmniejszało go wprowadzanie wciąż nowych form zatrudnienia elastycznego, dualnego rynku pracy, segmentacja zatrudnienia czy umowy zlecenia, umowy o dzieło czy tzw. samozatrudnienie. Nowe wyrażenia, mające opisywać tę sytuację na rynku pracy, nie były zdolne jej zmienić, pomimo zużywania na ten cel środków finansowych, w tym środków Unii Europejskiej. W końcu 2016 roku bezrobocie spadło do poziomu około 8,2 proc., ale stopa zatrudnienia nie wzrosła $w$ takim samym stopniu, jak spadło bezrobocie. W publicznie wyrażanej ocenie spadek bezrobocia to wynik rozwoju gospodarki. Jednak analiza emigracji zarobkowej i, szerzej, sytuacji demograficznej pokazuje, że spadek bezrobocia w Polsce osiągnięto głównie w wyniku bardzo wysokiego poziomu emigracji zarobkowej. W 2015 roku za pracą lub w związku z pracą wyemigrowało z Polski 2 mln 438 tys. osób. Gdyby tych, którzy wyemigrowali, zaliczyć do bezrobotnych w Polsce, to uzyskany wynik trzeba byłoby powiększyć ok. 2,5-krotnie. Brak pracy w okresie transformacji spowodował w Polsce w masową emigrację młodych ludzi, „za chlebem”. Niskie bezrobocie nie zmieni sytuacji prekariuszy. Neoliberalna gospodarka będzie szukała taniej siły roboczej w dowolnym kraju - przenosząc produkcję tam, gdzie ona jest, lub sprowadzając „tanich” pracowników do Polski.

Państwowe instytucje polityki społecznej miały bronić społeczeństwo, naród i państwo przed zagrożeniami, jakie niosła narastająca kwestia społeczna, będąca skutkiem działania „nie-

28 Por. GUS, Wyniki Narodowego Spisu Powszechnego 2002.

29 GUS, Wyniki Narodowego Spisu Powszechnego 2002 i 2011. 
okiełznanych sił wolnego rynku". Tych sił, które jedni uważali za szkodliwe, a inni za żywioł uzdrawiający liberalną gospodarkę. Od XIX wieku państwa europejskie powszechnie angażowały się w ograniczenie i zmniejszenie skutków działania niszczącej siły wolnego rynku i jej wpływu na poziom zatrudnienia. Na przełomie XX i XXI wieku instytucje polityki społecznej zrezygnowały z aktywności w zakresie ochrony pracy i pracowników; zabrakło bezpośredniego zaangażowania państwa $\mathrm{w}$ przeciwdziałanie negatywnym skutkom globalnej gospodarki neoliberalnej. Tak powstała w XXI wieku nowa kwestia społeczna czy - jak pisał Ralf Dahrendorf - „nowoczesny konflikt społeczny”, którego źródłem są głębokie zmiany w systemie pracy, wpływające na życie jednostek i struktury społeczne ${ }^{30}$.

30 R. Dahrendorf, Nowoczesny konflikt społeczny. Esej o polityce wolności, Warszawa 1993. 